\title{
Skeletopy of the medullary cone in Sapajus apella: Clinical implications in epidural anesthesia
}

\section{Esqueletopia do cone medular em Sapajus apella: Implicações clínicas na anestesia epidural ${ }^{*}$}

Jessica Albuquerque Lopes, ${ }^{* *}$ Raysa Melul, ${ }^{* * * * *}$ Cíntia Francieli do Prado, ${ }^{* * * *}$ Érika Branco, ${ }^{* *, * *}$ Ana Rita de Lima ${ }^{* *, * * *}$

\begin{abstract}
This work aimed to describe the skeletopy of the medullary cone of the capuchin monkey (Sapajus apella) and to lay morphological foundations to propose a route of administration for epidural anesthesia. We used five females adults $S$. apella, and dissected them to study their medullary cone. The fixated animals were dissected, a skin incision was made from the dorsal median line, epaxial musculature and vertebral arcs was removed to expose the spinal cord, individualizing the medullary cone and the lumbar intumescence. The base of S. apella medullary cone was located near the L5 vertebra and the apex near S3, the structure was $4.5 \mathrm{~cm}$ in average. The evaluated specimens presented five lumbar and four sacral vertebrae. We concluded that the positioning of $S$. apella medullary cone is caudally than in other species, suggesting that the most appropriate location for epidural anesthetic procedures is the sacrocaudal region.
\end{abstract}

Keywords: capuchin monkey, epidural anesthesia, nervous system, skeletopy.

\section{Resumo}

Este estudo visa descrever a esqueletopia do cone medular em macaco prego (Sapajus apella), com a intenção de estabelecer bases morfológicas para prestar o apoio à implementação de procedimentos anestésicos e outros procedimentos de rotina clínica-cirúrgica veterinária, dada a crescente importância do papel do veterinário na saúde dos animais selvagens. Cinco $S$. apella adultos fêmeas foram utilizadas neste trabalho e dissecados para o estudo do cone medular. Os animais fixados foram dissecados, foi feita uma incisão na pele na linha média dorsal, a musculatura epaxial e os arcos vertebrais foram removidos para exposição da medula espinhal, individualizando o cone medular e a intumescência lombar. A base do cone medular do $S$. apella foi observada na altura da vértebra L5 com o ápice em S3, com comprimento médio de 4,5 cm. Os espécimes avaliados apresentaram cinco vértebras lombares e quatro sacrais. Conclui-se que o posicionamento do cone medular do $S$. apella é mais caudal em relação às outras espécies. Por conseguinte, é sugerido que o local mais apropriado para o procedimento anestésico peridural é a sacrocaudal região.

Palavras-chave: anestesia epidural, esqueletopia, macaco prego, sistema nervoso.

\section{Introduction}

Appropriate knowledge of the morphology and skeletopy of the nervous system of different animal species is considered relevant to the veterinary surgical field. This knowledge is crucial to perform maneuvers such as liquor puncture, to locate central nervous lesions at specific vertebral levels (Dyce, 2010), and to carry out myelography exams and cerebrospinal fluid punctures (Cordeiro et al., 2014) without posing unnecessary risks to the animal's health.

Understanding the nervous system is also crucial to propose anesthesia protocols for surgical procedure in the different species. Epidural anesthesia is the most used regional anesthetic technique due to its efficiency, safety, convenience, swiftness, and low cost (Fantoni e Cortopassi, 2009) and consists on injecting local anesthetics in the epidural space, located between the dura mater and the vertebral canal. However, it can cause cardiovascular complications that can be easily compensated in healthy animals, but irreversible in cardiac patients. Thus, it is necessary to carefully evaluate the clinical condition of the patient before deciding to use this technique (Intelizano et al., 2002).

The ideal location for anesthetic administration in the epidural space varies for each species depending on where the spinal cord culminates. The choice of locations caudal to the medullary cone

\footnotetext{
${ }^{*}$ Recebido em 25 de fevereiro de 2019 e aceito em 4 de junho de 2019.

**Faculdade de Medicina Veterinária da Universidade Federal Rural da Amazônia - UFRA, Instituto de Saúde e Produção Animal - ISPA, Laboratório de Pesquisa Morfológica Animal, Belém-PA, Brasil.

***Programa de Pós Graduação em Saúde e Produção Animal na Amazônia - PPGSPAA. Belém-PA, Brasil.

${ }^{* * * *}$ Centro Universitário da Fundação de Ensino Octávio Bastos - UNIFEOB, São João da Boa Vista-SP. Brasil.

Correspondence author: Ana Rita de Lima - vetlima@uol.com.br.
} 
makes the administration safer and avoids lesions to the spinal cord (Hilbery, 1992). Therefore, a morphological knowledge of the relations between the spinal cord and the vertebral column is usually needed to propose suitable protocols for epidural/spinal anesthesia that are necessary to perform quality treatments in animals needing surgical interventions in caudal and retro umbilical-located tissues (Fantoni and Cortopassi, 2009), and in some intra-abdominal procedures (urinary vesicle, rectum, prostate and uterus surgery) (Klaumann e Otero, 2013).

Although the knowledge on medullary cone positioning is available for the species of primates Saimiri sciureus (Lima et al., 2011a), Saguinus midas (Martins et al., 2013), Callithrix jacchus (Silva et al., 2013) and Sapajus libidinosus (Cordeiro et al., 2014), this information has not yet been described for Sapajus apella.

As the prominence of the veterinary care of wild animals increases, a detailed description for each species becomes necessary to provide the best clinical care, since even among species of the same family it is not possible to determine universal values and general procedures. This work aimed to investigate the skeletopy of the medullary cone in $S$. apella and to propose the best location to administer epidural anesthesia. We expect that this knowledge will increase the safety of procedures like liquor collection, and myelography.

\section{Material and methods}

Five S. apella females who died from natural causes were provided by the Centro Nacional de Primatas Institute - CENP _ located in Ananindeua city, Pará state, Brazil. All procedures were approved by the Comitê de Pesquisas com Animais (CEPAN/ IEC/SVS/MS), $n^{\circ}$ 008/2010.

Animals who died from natural causes were sent to the Animal Morphological Research Laboratory of the Federal Rural University of Amazonia (LaPMA / UFRA), where the specimens were fixated using an intramuscular infusion of an aqueous solution of $10 \%$ formaldehyde, followed by the submersion of the animal in the same solution, for at least seven days.

The fixated animals were dissected using basic techniques. A skin incision was made from the dorsal median line from the thoracolumbar region to the base of the tail, followed by removal of the epaxial musculature at the same level. Then, the vertebral arcs were removed to expose the spinal cord, individualizing the medullary cone and the lumbar intumescence. The cauda equine and medullary cone were measured using a digital caliper.

The adopted nomenclature was based on the Nomina Anatomica Veterinaria (International Committee on Veterinary Gross Anatomical Nomenclature, 2017).

\section{Results and discussion}

The five $S$. apella individuals had five lumbar and four sacral vertebrae (Figure 1A). The base of the medullary cone was located caudally to the lumbar intumescence and cranially to the cauda equina, at the level of the fifth lumbar vertebra (L5). In all animals the apex was located at the level of the third sacral vertebra (S3). The structure had in average $4.5 \mathrm{~cm}$ long. The cone was immediately covered by the dura mater, which showed no prolongation. Consequently, no dural sac was formed (Figure 1B).
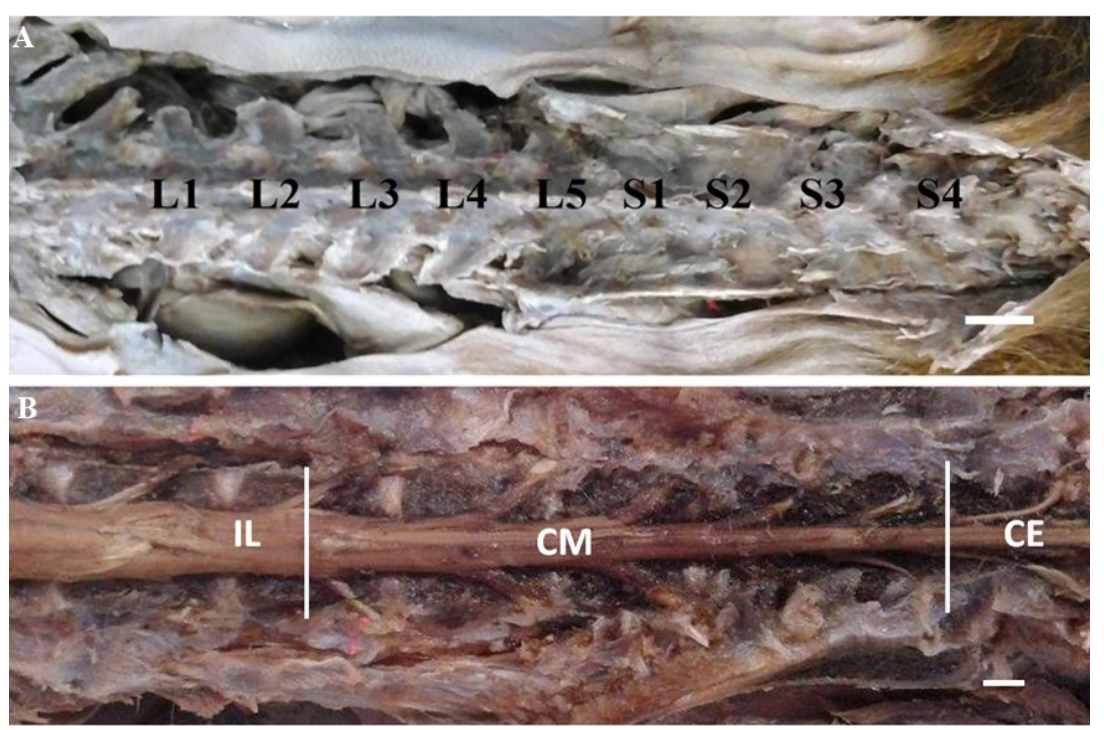

1: A - Photomacrography in dorsal view of the vertebral column of the $S$. apella following intumescence (LI) and cauda equina (CE). Scale bar: $1 \mathrm{~cm}$.

In species that do not present the dural sac as is the case of $S$. apella, the risk of neurological injury is high if the anesthesiologist does not have the skill and precision to administer epidural anesthesia (Ganem, 2006) in this way, the injury can be caused should the anesthesiologist access the subarachnoid space (O'Hearn and Wright, 2011).

The medullary cone of $S$. apella was larger than that of other small-sized primates of the same family (Cebidae), such as the common squirrel monkey (Saimiri sciureus) whose medullary was $3.3 \mathrm{~cm}$ long (Lima et al., 2011a), the common marmoset (Callithrix jacchus), $1.64 \mathrm{~cm}$ long (Silva, 2013), and the blackstripped capuchin (Sapajus libidinosus), $2.47 \mathrm{~cm}$ long (Cordeiro, 2014); but smaller than that of the red-handed tamarin (Saguinus midas), $5.14 \mathrm{~cm}$ long (Martins et al., 2013).

The skeletopy of the medullary cone varies considerably between species of the Cebidae family. In S. apella, the medullary cone was located between L5 and S3, whereas in Saguinus midas (Martins et al., 2013) and Callithrix jacchus (Silva et al., 2013) it was located more cranially, between L4 and S2, and L2 and L5, respectively; and in Saimiri sciureus it was located more caudally, between L7-8 and S3 or Cd1 (Lima et al., 2011). These differences in the skeletopy of the medullary cone further suggest that there is no relation between the length and location of the structure and the body size of the animal.

The Xenarthras also present unrelated morphologies, for example, in the brown-throated sloth (Bradypus variegatus), the medullary cone is located between L3 and S1 (Lima et al., 2011b); in the southern tamandua (Tamandua tetradactyla), it is located 
between L1 and L5-L6 (Machado e Santos, 2008); and in the giant anteater (Myrmecophaga tridactyla), it is located between L3 and S2 (Ribeiro et al., 2015). The different topographies observed in these animals emphasize the necessity of a detailed description for each species since even among the same clades, it is not possible to determine universal values and surgicalclinical anesthetic procedures.

The variation of the adequate vertebral space for the execution of epidural anesthesia directly affects the success of trans operatory anesthetic procedures and the recovery of the patient (Tudury et al., 2014). To propose a safe puncture site for epidural anesthesia in S. apella it was necessary to compare the data to those of mammals of other groups because data for species of the same group were lacking.

$S$. apella featured a medullary cone topography similar to that of the ocelot (Leopardus pardalis), located between L4 and S3 (de Santa Brigida et al., 2010), but with a length of $8.5 \mathrm{~cm}$. The medullary cones of the ring-tailed coati (Nasua nasua) (Branco et al., 2010) and the jaguarundi (Puma yagouaroundi) (Carvalho et al., 2003) were similar in skeletopy and length to that of $S$. apella. The medullary cone in the coati was located between L5-6 and S3 and was 5.2 to $5.8 \mathrm{~cm}$ long; and in the jaguarundi, it was located between L6 and S2 and was $5 \mathrm{~cm}$ long. In the crab-eating fox (Cerdocyon thous), the medullary cone was located between L6 and S3 and was $10.13 \mathrm{~cm}$ long on average (Pinheiro et al., 2011).

Other a animals that presented a medullary cone with a topology similar to that of $S$. apella include the domestic cat (Felis catus), whose medullary cone began between vertebrae L5-7 and ended between S1-3 or Cd1-2 with an average length of $5.08 \mathrm{~cm}$ (Silva et al., 2009); the pampas fox (Lycalopex gymnocercus), whose medullary cone began between $L 5$ and $S 3$ and ended between L6 and Cd1 and was on average $6.8 \mathrm{~cm}$ long (Souza Junior et al., 2014); and the crab-eating-raccoon (Procyon cancrivorus), whose medullary was located between L4 and L7 and had an average length of $5.35 \mathrm{~cm}$ (Souza et al., 2014).
In other animals, the skeletopy of the medullary cone is different from that of $S$. apella. In the maned wolf (Chrysocyon brachyurus), the base of the medullary cone is at L3 and the apex at L5 (Machado et al., 2002); in the giant otter (Pteronura brasiliensis), the base is at L2 and the apex at L4 (Machado et al., 2009); in the tayra (Eira barbara), the base is at L3-L4 and the apex at L6 (Branco et al., 2013); and in the domestic dog (Canis familiaris), the base is at L3 and the apex at L7 (Santiago, 1974), allowing access to the epidural space through the lumbarsacral articulation. In the animals mentioned in this paragraph, epidural anesthesia must be performed in the lumbar-sacral region, whereas in $S$. apella and other aforementioned nonhuman primates the same anesthetic procedure must be performed in the sacrococcygeal region.

The South American fur seal (Arctocephalus australis), a semiaquatic carnivore, has its medullary cone located between T5 and T7. However, it was described that for safety reasons and aiming to avoid apnea conditions, the anesthetic block in this species must occur at the most caudal region of the medullary cone (Machado et al., 2003).

The paca (Agouti paca), is a rodent of South American origin. Its medullary cone was located between the vertebrae L5 and S1 (Scavone et al., 2007). The medullary cone of the sheep (Ovis aries) started either between L5-6, or L6-S1, and ended between S1-S3 (Santos e Lima, 2000).

\section{Conclusion}

The medullary cone of the $S$. apella features differences in length and skeletopy when compared to other primates and wild mammals. It is possible to conclude that the medullary cone of the $S$. apella is located more caudally than in other species, having its base at the L5 vertebra and its apex at S3, which provides a suggestive location for epidural anesthetic punction at the interarcual space of the sacrocaudal junction.

\section{Acknowledgements}

The authors thank the National Centre of Primates (CENP)/Ananindeua-PA for their support. And to the Federal Rural University of Amazonia, Research and Technological Development Pro-Rectory, Program to support to publication, Edital Proped $07 / 2018$.

\section{References}

BRANCO, E.; LINS, F.L.M.L.; PEREIRA, L.C.; LIMA, A.R. Topografia do cone medular da irara (Eira barbara) e sua relevância em anestesias epidurais. Pesquisa Veterinária Brasileira, v.33, n.6, p.813-816, 2013.

BRANCO, É.; GREGORES, G.B.; SARMENTO, C.A.P.; MIGLINO, M.A.; CORTOPASSI, S.R.G.; DE CARVALHO, A.F.; DE OLIVEIRA, P.C.; FERREIRA, G.J.B.C.; CABRAL, R.M.; FIORETTO, E.T. Topografia do cone medular do quati (Nasua nasua, Linnaeus, 1766). Biotemas, v.23, n.2, p.173-176, 2010.

DE SANTA BRÍGIDA, S.S. BRANCO, E.; PINHEIRO, L.P.; MARTINS, D.M.; ARAÚJO, E.B.; MELUL, R.; LACRETA JR, A.C.C.; MENESES, A.M.C.; SOUZA, A.C.B.; PEREIRA, L.C.; FIORETTO, E.T.; LIMA, A.R. Topografia do cone medular da jaguatirica (Leopardus pardalis). Acta Veterinaria Brasilica, v.4, n.1, p.51-54, 2010.
CARVALHO, S.F.M.; SANTOS, A.L.Q.; AVILA JUNIOR, R.H.; ANDRADE, M.B.; MAGALHÃES, L.M.; MORAES, F.M.; RIBEIRO, P.I.R. Topografia do cone medular em um gato-mourisco, Herpailurus yagouaroundi (Severtow, 1858). Archives of Veterinary Science, v.8, n.2, p.35-38, 2003.

Cordeiro, J.F.; Santos, J.R.S.; Dantas, S.B.A.; Fonseca, S.S.; Dias, R.F.F.; Medeiros, G. X.; Nobrega Neto, P.I.; Menezes, D.J.A. Anatomia do cone medular aplicada à via epidural de administração de fármacos em macacos-prego (Sapajus libidinosus). Pesquisa Veterinária Brasileira, v. 34, n.1, p. 29-33, 2014.

DYCE, K.M.; SACK, W.O.; WENSING, C.J.G. Tratado de Anatomia Veterinária. Rio de Janeiro: Guanabara Koogan, 2010. 834p.

INTELIZANO, T.R.; FANTONI, D.T.; CORTOPASSI, S.R.G. Técnicas de anestesia local. In: FANTONI, D.T.; CORTOPASSI, S.R.G. Anestesia em cães e gatos. São Paulo: Roca, cap.19. 2002. p.199-208. 
FANTONI, D.T.; CORTOPASSI, S. R. G. Anestesia em cães e gatos. 2 ed. São Paulo: Roca, 2009. 622p.

GANEM, E.M. Complicações neurológicas da anestesia peridural e subaracnóidea. In: CAVALCANTI, I.L.; CANTINHO, F.A.F.; ASSAD, A. (eds.) Medicina Perioperatória. Rio de Janeiro: Sociedade de Anestesiologia do Estado do Rio de Janeiro, 2006, p.197-201.

HILBERY, A.D.R. Manual de Anestesia de los Pequeños Animales. Acribia: Zaragoza, España. 1992. 240p.

INTERNATIONAL COMMITTEE ON VETERINARY GROSS ANATOMICAL NOMENCLATURE. Nomina Anatomica Veterinaria. 6th Edition. Hannover: Editorial Committee, 2017. 178p.

KLAUMANN, P.R.; OTERO, P.E. Anestesia locorregional do neuroeixo. In: Anestesia locorregional em pequenos animais. São Paulo: Roca, 2013. p. 135-176.

LIMA, A.R.; FIORETTO, E.T.; FONTES, R.F.; IMBELONI, A.A.; MUNIZ, J.A.P.C.; BRANCO, E. Caring about medullary anesthesia in Saimiri sciureus: the conus medullaris topography. Anais da Academia Brasileira de Ciências. v.83, n.4, p.1339-1344, 2011a.

LIMA, A. R.; COSTA, A.M.; FIORETTO, E.T.; SANTIAGO, H.R.V.; CARMO, D.C.; BRANCO, E. Topografia do cone medular da preguiça. Pesquisa Veterinária Brasileira, v.31, n.7, p.627-630, 2011b.

MACHADO, G.V.; FONSECA, C.C.; DAS NEVES, M.T.D.; DE PAULA, T.A.R.; BENJAMIN, L.A. Topografia do cone medular no lobo-guará (Chrysocyon brachyurus Illiger, 1815). Revista Brasileira de Ciência Veterinária, v. 9, n. 2, p. 107-109, 2002.

MACHADO, G.V.; SANTOS, P. Topografia do cone medular no tamanduá-mirim (Tamandua tetradactyla, Linnaeus, 1758) (Xenarthra: Myrmecophagidae). Archives of Veterinary Science, v.13, n.3, p. 172-175, 2008.

MACHADO, G.V.; LESNAU, G.G.; BIRCK, A.J. Topografia do cone medular no lobo marinho (Arctocephalus australis Zimmermann, 1783). Arquivos de Ciências Veterinárias e Zoologia da UNIPAR, v. 6, p. 11-14, 2003.

MACHADO, G.V.; CAL, J.A.; BIRCK, A.J. Topografia do cone medular no ratão-do-banhado (Myocastor coypus Molina, 1782 Rodentia: Mammalia). Biotemas, v.22, n.2, p.117-120, 2009.

MACHADO, G.V.; ROSAS, F.C.; LAZZARINI, S.M. Topografia do cone medular na ariranha (Pteronura brasiliensis, Zimmermann, 1780). Ciência Animal Brasileira, v.10, n.1, p.301-305, 2009.

MARTINS, D.M. PINHEIRO, L.L.; LIMA, A.R.; PEREIRA, L.C.; BRANCO, E. Topografia do cone medular do sauim (Saguinus midas). Ciência Rural, v.43, n.6, p.1092-1095, 2013.
O'HEARN, A.K.; WRIGHT, B.D. Coccygeal epidural with local anesthetic for catheterization and pain management in the treatment of feline urethral obstruction. The Journal of Veterinary Emergency and Critical Care (San Antonio), v.21, p. 50-52. 2011.

PINHEIRO, L.L.; DE LIMA, A.R.; DE SOUZA, A.C.B.; PEREIRA, L.C.; BRANCO, É. Topografia do cone medular do cachorrodo-mato (Cerdocyon thous, Linnaeus, 1766): relato de caso. Biotemas, v. 24, n. 4, p. 129-133, 2011.

RIBEIRO, L.A.; DE SOUZA, T.A.M.; RIBEIRO, P.R.Q.; DOS SANTOS, L.A.; SILVA, D.C.O.; SILVA, F.O.C.; BARROS, R.A.C.; ZANON, R.G. Topografia do cone medular do Tamanduá-bandeira (Myrmecophaga tridactyla, Linnaeus, 1758). Revista Brasileira de Medicina Veterinária, v. 37, n.4, p.353-358, 2015.

SANTIAGO, W. Esqueletopia do cone medular em Canis familiaris. Arquivo da Universidade Federal Rural do Rio de Janeiro, v. 4, n. 1, p. 67-69, 1974.

SANTOS, A.L.Q.; DE LIMA, E.M.M. Topografia do cone medular em ovinos sem raça definida (Ovis aries, Linnaeus, 1758). Ars Veterinaria, v. 16, n. 3, p.154-157, 2000.

SCAVONE, A.R.F.; GUIMARÃES, G.; RODRIGUES, V.; SASAHARA, T.; MACHADO, M.R.F. Topografia do cone medular da paca (Agouti paca, Linnaeus - 1766). Brazilian Journal of Veterinary Research and Animal Science, v. 44 (supl.), p. 53-57, 2007. https://doi.org/10.11606/issn.1678-4456.bjvras.2007.26590

SILVA, P.H.C.; SILVA, R.M.; LIMA, E.M.M. Topografia do cone medular em gatos sem raça definida. Arquivo Brasileiro de Medicina Veterinária e Zootecnia, v.61, n.5, p.1062-1066, 2009.

SILVA, L.C.S.; BARROSO, C.E.; PAVANELO JUNIOR, V.; BOMBONATO, P. B. Topografia vértebro-medular em sagui-detufo-branco (Callithrix jacchus, LINNAEUS 1758). Ciência Animal Brasileira, v.14, n.4, p.462-467, 2013.

SOUZA, D.R.; FERREIRA, L.S.; PEREIRA, D.K.S.; HELRIGLE, C.; PEREIRA K. F. Topografia do cone medular de Procyon cancrivorus. Bioscience Journal, v. 30, n. 3, p. 823-829, 2014

SOUZA JUNIOR, P.; DE MATTOS, K.; DE CARVALHO, N.C.; SANTOS, A.L.Q. Topografia da intumescência lombar e do cone medular em Lycalopex gymnocercus. Revista Brasileira de Ciência Veterinária, v. 21, n. 3, p. 173-177, 2014.

TUDURY, E.A.; FERNANDES, T.H.T.; FIGUEIREDO, M.L.; ARAÚJO, B.M.; BONELLI, M.A.; SILVA, A.C.; SANTOS, C.R.O. Anestesia epidural na cirurgia descompressiva lombossacral de cães. Arquivo Brasileiro de Medicina Veterinária e Zootecnia, v.66, n.3, p.787-796, 2014. 